\title{
Germination of Syzygium malaccense and Syzygium jambos seeds under different thermal conditions and seedling morphology
}

\author{
Guilherme Nacata ${ }^{1} \&$ Renata Aparecida de Andrade ${ }^{2}$
}

\begin{abstract}
The objective of this research was to analyze the influence of temperature on seed germination and seedling morphology for the $S$. malaccense and $S$. jambos. For germination, 250 seeds of each species, of ripe fruits, were used, which were washed in running water, dried in room condition for 24 hours and disinfected. The seeds were placed in plastic boxes with medium texture vermiculite substrate and submitted to different temperatures: $20,25,30,35^{\circ} \mathrm{C}$ and $20-30^{\circ} \mathrm{C}$ in BOD 'S, in a completely randomized design. The variables analyzed were: daily germination percentage, polyembryony and GSI. For morphological characterization, 30 seeds of both each species, submitted to a temperature of $30^{\circ} \mathrm{C}$ and samples were collected at intervals representative of the germination. There is no influence of temperature on the germination of $S$. malacense seeds and for $S$. jambos there are losses of $35^{\circ} \mathrm{C}$. The temperatures of $2520-30$ and $30^{\circ} \mathrm{C}$, influence the highest percentage of polyembryony for $S$. malaccense, for $S$. jambos, only the temperature of $35^{\circ} \mathrm{C}$ affected this process. The temperatures of 20 and $25^{\circ} \mathrm{C}$ decreased the GSI, for both species. The seeds have green cotyledons, hypogeal germination with brown primary root and whitish, short and filiform secondary roots.
\end{abstract}

Index terms: Seed physiology, abiotic factors, exotic fruits, propagation.

\section{Germinação de sementes de Syzygium malaccense e Syzygium jambos em diferentes temperaturas e morfologia das plântulas}

Corresponding author: guilhermenacata@usp.br

Received: October 15, 2019 Accepted: April 14, 2020

Resumo -Objetivou-se com a presente pesquisa analisar a influência da temperatura na germinação de sementes e a morfologia das plântulas para os $S$. malaccense e $S$. jambos. Para germinação, foram utilizadas 250 sementes de cada espécie, de frutos maduros, que foram lavadas em água corrente, secas em condição ambiente por 24 horas e desinfestadas. As sementes foram colocadas em caixas plásticas com substrato vermiculita textura média e submetidas a diferentes temperaturas: $20 ; 25$; $30 ; 35^{\circ} \mathrm{C}$ e $20-30^{\circ} \mathrm{C}$ em BODs, em delineamento inteiramente casualizado. As variáveis analisadas foram: porcentagem diária de germinação, poliembrionia e índice de velocidade de germinação Copyright: All the contents of this (IVG). Para caracterização morfológica, foram utilizadas 30 sementes de cada espécie de Syzygium,
journal, except where otherwise(IV). noted, is licensed under a Creative submetidas à temperatura de $30^{\circ} \mathrm{C}$, sendo coletadas amostras com intervalos representativos do Commons Attribution License. processo germinativo. Não há influência da temperatura na germinação das sementes de $S$. malaccense, e para o $S$. jambos há prejuízos a $35^{\circ} \mathrm{C}$. As temperaturas de $25 ; 20-30$ e $30^{\circ} \mathrm{C}$, influenciam na maior porcentagem de poliembrionia para $S$. malaccense, já para $S$. jambos, apenas a temperatura de 35 ${ }^{\circ} \mathrm{C}$ afetou esse processo. As temperaturas de 20 e $25^{\circ} \mathrm{C}$ diminuíram o IVG, para ambas as espécies. As sementes apresentam cotilédones de coloração verde, germinação hipógea com raiz primária de coloração marrom e secundárias esbranquiçadas, curtas e filiformes.

Termos para indexação: Fisiologia da semente, fatores abióticos, frutífera exótica, propagação.

\footnotetext{
${ }^{1}$ Agronomist., PhD student in Agronomy (Phytotechnics), University of São Paulo, Escola Superior de Agricultura "Luís de Queiroz", Piracicaba-SP. E-mail: guilhermenacata@usp.br(ORCID 0000-0002-7797-9267)

${ }^{2}$ Agronomist., Teacher. Assist. PhD., São Paulo State University “Júlio de Mesquita Filho”, College of Agricultural and Veterinary Sciences,

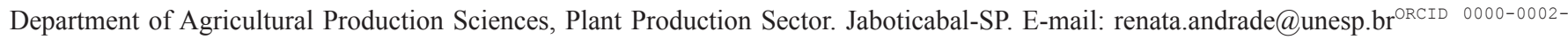
9795-7049)
} 


\section{Introduction}

The genus Syzygium, belonging to the Myrtaceae family, is composed of fruit trees of tropical climate that originate from the Indomalayan region (OLIVEIRA et al., 2015). The knowledge of the dispersal unit of a species is important for its establishment and multiplication; nevertheless, for the culture of Syzygium there is a lack of studies referring to the methods of propagation with practical applications, with the main route of propagation for Syzygium malaccense (L) (Meer \& Perry) being in general by seeds and cutting and for Syzygium jambos (L.) Alston, the propagation by seeds is usually employed (RAYDIN et al., 2014; AGUIAR NETO, 2016; PATEL, 2016; VYAS et al., 2017; YUSNITA et al., 2017).

Among the existing propagation methods, the sexed route is the main method of plant multiplication, both in nature and in cultivation (TAIZ et al., 2017). In fruticulture, this pathway is primarily used for rootstock production, since a commercial orchard consisting of seedlings originating from seeds presents some limitations, such as long period of youthfulness, large size of the plants and wide genetic variability (RAYDIN et al., 2014; DEWAN et al., 2018).

Germination starts with the supply of water to the seed and ends when the radicle is released through the integument (TAIZ et al., 2017). Similarly, to the intrinsic factors of the seed itself, the environmental factors, such as water, temperature and gas concentration, greatly influence seed germination. Among the external factors, temperature affects not only the capacity of germination, but also the rate at which it occurs, with a defined range for each species. According to Carvalho and Nakagawa (2012) and Menezes et al. (2018), the optimum temperature is considered as the one which allows the maximum germination in the shortest period of time and, usually, the maximum germination speed occurs at temperatures little above those which ensure the maximum percentage.

The knowledge of the morphological characteristics of germination is important to gather data on seed biological cycle, being applied in the management and production of seedlings, differentiation of taxonomic groups, works on the improvement and conservation of a species, since the emergence and initial development of the seedlings are indispensable stages in plant life cycle (SEVIK; GUNEY, 2016; FERRAZ et al., 2018).

In the available literature, there is a lack of studies and morphologically characterize the response of $S$. malaccense and $S$. jambos and information on the ideal temperature to germination. This work aims to verify the influence of temperature on seed germination, morphologically characterizing the steps of $S$. malaccense and $S$. jambos germination process.

\section{Material and methods}

The experiment was performed at the Laboratory of Fruit Seeds of the Department of Plant Production of FCAV/UNESP, Campus of Jaboticabal, using seeds extracted from ripe fruits from $S$. malaccense and $S$. jambos. After extraction, that was realized by simply removing the seed from the pulp, were washed in running water, dried under ambient conditions $\left( \pm 25^{\circ} \mathrm{C}\right)$ for 24 hours and disinfested, by sequential immersion, for 30 seconds, in $70 \%$ alcohol, $2 \%$ hypochlorite and the fungicide Mancozebe (i.a.) at $2 \%$.

The sowing was carried out in plastic boxes, with medium textured vermiculite substrate, and then conditioned in germ chambers of the Biochemical Oxygen Demand (BOD) type, with photoperiod 10 of without light and 8 hours of light, and at different temperatures: $20 ; 25$; $30 ; 35^{\circ} \mathrm{C}$ and alternated from $20-30^{\circ} \mathrm{C}$, each treatment being subdivided into 5 repetitions, with experimental unit formed by 10 seeds

The experiment lasted for 16 weeks for $S$. malaccense and 17 weeks for $S$. jambos, being this period determined by the complete stabilization of the germination. The evaluation was performed regarding: a) the daily percentage of germination, computing the emergence (normal seedlings); and b) rate of polyembryony, counting, at the end of the complete germination, the number of plants that emerged from each seed, in all temperatures tested.

The germination speed index (GSI) was calculated using the daily data obtained on the germination, using the calculation formula from Maguire (1962): $\mathrm{GSI}=\left(\mathrm{G}_{1} /\right.$ $\left.\mathrm{N}_{1}\right)+\left(\mathrm{G}_{2} \mathrm{~N}_{2}\right)+\left(\mathrm{G}_{3} / \mathrm{N}_{3}\right)+\ldots+\left(\mathrm{G}_{\mathrm{n}} / \mathrm{N}_{\mathrm{n}}\right)$, with: $\mathrm{G}_{1}, \mathrm{G}_{2}, \mathrm{G}_{3}$, $\mathrm{G}_{\mathrm{n}}=$ number of seedlings computed at the first, second, third and last count; $\mathrm{N}_{1}, \mathrm{~N}_{2}, \mathrm{~N}_{3}, \mathrm{~N}_{\mathrm{n}}=$ number of days from sowing to the first, second and last count.

The morphological description was made of 30 seeds, which were conditioned at a temperature of $30^{\circ} \mathrm{C}$, which positively influenced their germination. The characterization of germination process followed the methodology of (COSTA et al., 2006) with adaptations and the illustrations of the germination process were performed using a digital camera. A total of 30 seeds from each species seeds from each species of $S$. malaccense and $S$. jambos were used, and sown in containers with mediumtexture vermiculite. Daily evaluations were conducted and from the observation of the emission of the primary root, samples from representative stages of the germination process were collected: development of the primary root; emergence of secondary roots and expansion of the cotyledons; beginning of the growth of the first leaf and conspicuous apical bud; expansion of the primary leaf and beginning of the development of the second leaf; young plant, with nomophylls and cotyledons in early demise, and each stage was stored in a recipient containing $70 \%$ 
alcohol, to later describe the stages of development

For germination, the completely randomized design method was adopted, using two species of Syzygium (malaccense and jambos) and five temperatures $(20 ; 25$; $\left.30 ; 35 ; 20-30^{\circ} \mathrm{C}\right)$, transforming the percentage data into arc-sine, $\sqrt{x / 100}$ data transformation was necessary to ensure data normality, for purposes of statistical analyses. The data were submitted to analysis of variance and the media compared to each other by the test Tukey`s 5\% probability. The program employed for the statistical analyses was SAS version 9.0.

\section{Results and discussion}

S. malaccense seed germination is not influenced by the temperature to which the seeds are subjected (Table 1), but this is not verified for $S$. jambos seeds, for which the worst germination performance at the temperature of $35^{\circ} \mathrm{C}$. For species with the center of origin in tropical regions, such as the case of the species studied, the optimum range of germination is between 20 and $35^{\circ} \mathrm{C}$, each species responding differently (CARVALHO; NAKAGAWA, 2012).

Table 1. Germination rate of seeds from $S$. malaccense and $S$. jambos subjected to different temperatures.

\begin{tabular}{ccl}
\hline Temperature $\left({ }^{\circ} \mathrm{C}\right)$ & S. malaccense $*$ & S. jambos \\
\cline { 2 - 3 } 20 & $46 \mathrm{~A}$ & $83 \mathrm{~A}$ \\
25 & $61 \mathrm{~A}$ & $82 \mathrm{~A}$ \\
30 & $63 \mathrm{~A}$ & $90 \mathrm{~A}$ \\
35 & $61 \mathrm{~A}$ & $40 \mathrm{~B}$ \\
$20-30$ & $67 \mathrm{~A}$ & $85 \mathrm{~A}$ \\
\hline CV $(\%)$ & 16.63 & 20.10 \\
\hline$*$ Means followed by the same letter do not differ by the Tukey's test at 5\% of probability.
\end{tabular}

The influence of temperature is important for the germination process and inadequate temperatures, and can mainly affect the development of primary roots, as what are the first steps to develop in the germination process. A multiplication of cells for the growth or development of seedling structures, occurs quickly and any factor of temperature, water and soil, can lead to a decrease in growth capacity (GUIJARRO-REAL, et al., 2020).

The influence of elevated temperatures in several plant species, leading to negative effects on the activity of enzymes, causing a disorganization in the cell membranes (reduction in permeability and restrictions in oxygen access), decrease in the supply of free amino acids, reduction in RNA synthesis, reduction in the speed of metabolic reactions, besides fostering contamination by microorganisms, leading to embryo deterioration (BODRONE et al., 2017).

The response regarding germination percentage being negatively influenced at high temperatures $\left(35^{\circ} \mathrm{C}\right)$ is also reported in Tabebuia heptaphylla (RIBEIRO et al., 2012) and in three species of Myrciaria jaboticaba (Vell.) Berg, M. cauliflora (Mart.) Berg and M. peruviana var. trunciflora) (WAGNER JÚNIOR et al., 2015). Note that the seeds of $S$. Malaccense and S. Jambos showed a germination percentage of $60.63 \%$ and $40.54 \%$, respectively, at $35^{\circ} \mathrm{C}$. For the first species, the high temperature did not affect the seed germination process, when compared with the other treatments. For $S$. jambos, this temperature affected the germination of the seeds, reducing by half when compared to other treatments.
According to Mwamburi and Miller (2015), when seeds are exposed to high temperatures can drastically affect seed germination.

For the $S$. malaccense can be verified germination starts on the second week, after sowing, with the maximum germination rate occurring in the fifth week, then stabilizing (Figure 1). For S. jambos seeds, the germination process starts four weeks after sowing and the maximum germination occurred on the fifteenth week (Figure 2).

The occurrence of lack of germination or partial germination of the seeds depends on biotic and abiotic mechanisms (COMBS et al., 2013). Since in this experiment the factors such as water, oxygen, land temperature were controlled, the difference in germination percentage can be attributed to the temperature (TAIZ et al., 2017).

Physiologically, S. malaccense seed presents a faster degradation and mobilization of reserves (cotyledons) when compared to that from S. jambos; in other words, the process of mobilization and degradation is triggered during seed germination and extends until seedling establishment, involving the activation of different hydrolytic enzymes which catalyze de degradation of the reserve biomolecules, being transported to the embryonic axis by the phloem, providing energy and biosynthetic precursors that facilitate and increase germination speed (TAIZ et al., 2017). 


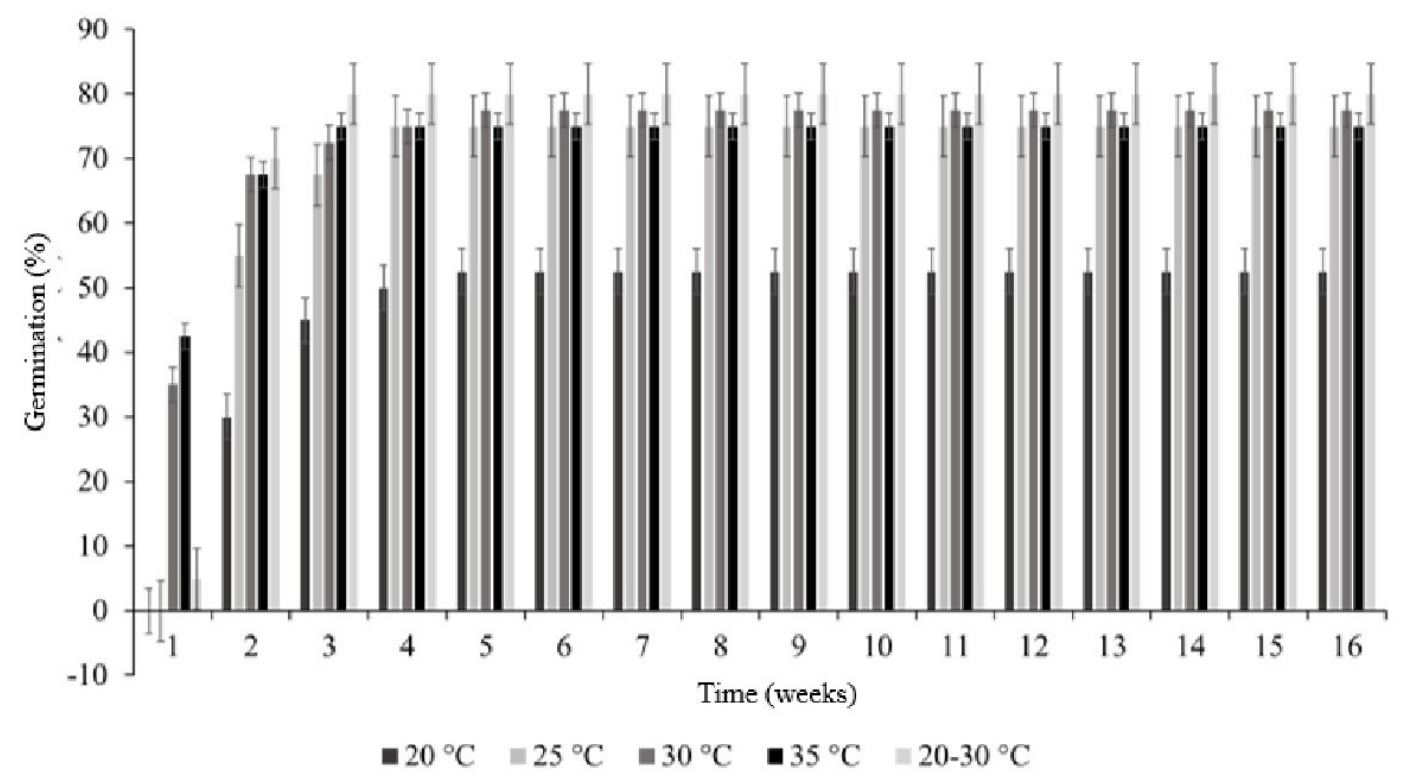

Figure 1. Weekly evolution of the percentage of germination of seeds from S. malaccense, subjected to different temperatures.

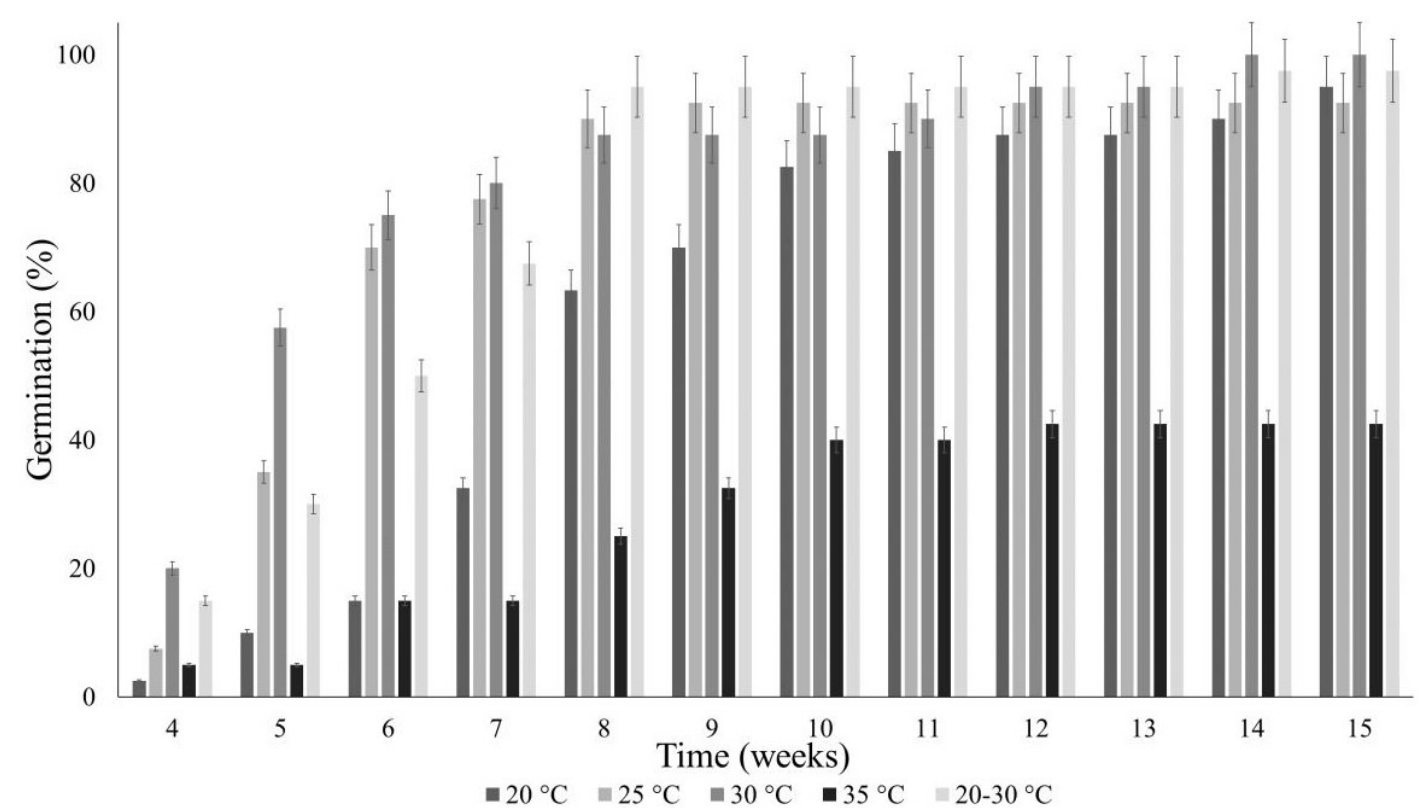

Figure 2. Weekly evolution of the percentage of germination of seeds from S. jambos, subjected to different temperatures

The fact of the fast reserve consumption of the cotyledon reserves, for $S$. malaccense, might have reduced the germination period to only four weeks, whereas for $S$. jambos this process occurs in a slower manner, which, on the other hand, guarantees energy provision for the embryonic organs for a longer period of time.

It is worth highlighting that $S$. malaccense seeds are bigger than those of $S$. jambos, and usually seeds with a bigger size present a larger amount of reserves, which can also be reflected in germination speed (HARTMANN et al., 2010; CARVALHO; NAKAGAWA, 2012; TAIZ et al., 2017).
There was no significant difference between the Syzygium species for the polyembryony rate, and $S$. jambos fits with a medium degree, with values between $40 \%$ and $70 \%$ of polyembryony and $S$. malaccense with a low degree, presenting values below 40\% (GURGEL; SOUBIHE SOBRINHO, 1951), disagreeing from (ALMEIDA, 2011; COSTA et al., 2006), who reported that $S$. malaccense originated from Recôncavo Baiano, Campinas, Araraquara and Piracicaba presented rates above $77 \%$, regardless of the temperature, with the classification of high polyembryony, which suggests that the rate of polyembryony can be influenced by the origin of the genotype. 
Polyembryony is a process in which more than one embryo is formed per seed, and these embryos might either originate from the zygote or by adventitious embryogenesis, originated from the differentiation of the nucellus cells, being identical to the mother plant (BEWLEY et al., 2013). This feature can be seen either positively, considering that more seedlings will originate from a single seed, or negatively, since the availability of reserves for each seedling is reduced, which might generate a decrease in their initial development (MENDES-RODRIGUES et al., 2011).
The highest values for the rate of polyembryony in S. malaccense were observed at the temperatures of 20-30, 25 and $30 \mathrm{C}$, whereas the lowest polyembryony values, both for $S$. malaccense and $S$. jambos, were verified at the temperature of $35^{\circ} \mathrm{C}$, this temperature being the only one to differ from the other temperatures for $S$. jambos (Table 2). For the species studied in this work, up to five embryos per seed were observed, which also happens in other fruit trees, such as the mango tree from the variety "espada" (SANTOS et al., 2009) and up to eight embryos in genotypes of the tangerines 'Dancy' and 'Sunki Tropical' (SANTOS et al., 2015).

Table 2. Polyembryony rate in seeds from S. malaccense and S. jambos subjected to different temperatures.

\begin{tabular}{ccc}
\hline Temperature $\left({ }^{\circ} \mathrm{C}\right)$ & S. malaccense & S. jambos \\
\cline { 2 - 3 } 20 & \multicolumn{2}{c}{$\%$} \\
25 & $49 \mathrm{~A}$ & $45 \mathrm{~A}$ \\
30 & $37 \mathrm{AB}$ & $53 \mathrm{~A}$ \\
35 & $26 \quad \mathrm{~B}$ & $51 \mathrm{~A}$ \\
$20-30$ & $51 \mathrm{~A}$ & $20 \mathrm{~B}$ \\
$\mathrm{CV}(\%)$ & 22.16 & $54 \mathrm{~A}$ \\
\hline * Means followed by the same letter do not differ from each other by the Tukey's test at $1 \%$ of probability.
\end{tabular}

There is an increase in the germination process for S. malaccense as the temperature rises, with the ranges of $25 ; 30 ; 35$ and $20-30^{\circ} \mathrm{C}$ providing the highest germination speed indexes (Table 3 ). The rise in temperature provides a higher water energy, causing greater diffusion, which simultaneously elevates the embryo's metabolic activity and reduces the internal potential of the seed, leading to a higher absorption of water and, consequently, greater hydration (TAIZ et al., 2017). It is important to emphasize that high temperatures also affect cell organization, hormone balance, decrease in the supply of free amino acids and in the synthesis of ribonucleic acid (RNA) (CARVALHO; NAKAGAWA, 2012), and this was probably the case of $S$. jambos, which had its germination influenced when the seeds were submitted to the temperature of $35^{\circ} \mathrm{C}$.

Table 3. Germination Speed Index (GSI) in seeds from S. malaccense and S. jambos subjected to different temperatures.

\begin{tabular}{ccc}
\hline Temperature $\left({ }^{\circ} \mathrm{C}\right)$ & S. malaccense & S. jambos \\
\hline 20 & $0.209 \mathrm{~B}$ & $0.204 \mathrm{AB}$ \\
25 & $0.332 \mathrm{AB}$ & $0.282 \mathrm{~A}$ \\
30 & $0.415 \mathrm{~A}$ & $0.321 \mathrm{~A}$ \\
35 & $0.424 \mathrm{~A}$ & $0.101 \mathrm{~B}$ \\
$20-30$ & $0.398 \mathrm{~A}$ & $0.282 \mathrm{~A}$ \\
\hline $\mathrm{CV}(\%)$ & 22.53 & 24.30 \\
\hline
\end{tabular}

* Means followed by the same letter do not differ by the Tukey's test at $5 \%$ of probability.

For the morphological characteristics of the germination of the two Syzygium species, it is observed that the seeds from $S$. malaccense and S. jambos are similar, being characterized as: polyembryonic, eurispermic, bitegumented, of dark brown coloration and exalbuminous (Figures 3 and 4). 


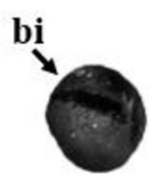

A

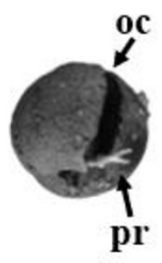

B

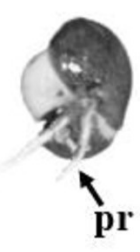

C

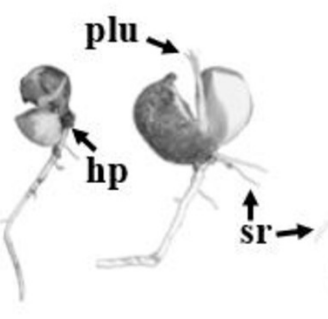

D
$\mathbf{E}$

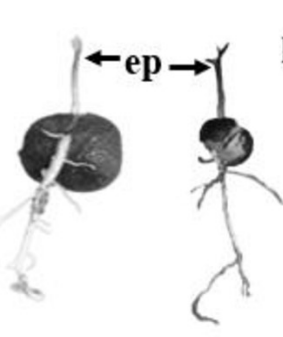

$\mathbf{F}$

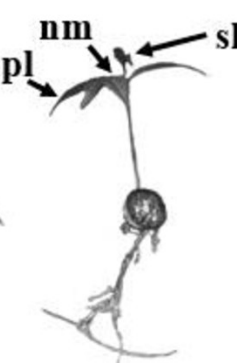

H

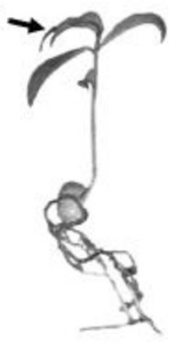

I

Figure 3. Sequence of germination of S. jambos seeds: A) breaking of the integument (bi); B) opening of the cotyledons (ac), primary root (rp); C) primary root (rp); D) hypocotyl (hp); E) plumule (plu), secondary roots(sr); F) epicotyl (ep), secondary roots (sr); G) epicotyl (ep); H) primary leaf, (pl), nomophylls (nm) . E) second pair of leaves in expansion; I) second pair of leaves in expansion (sl).

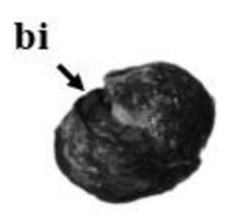

A

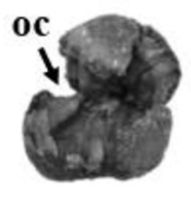

B

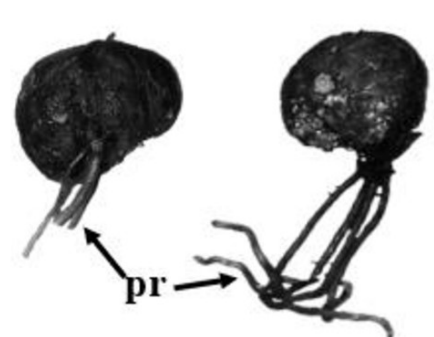

C

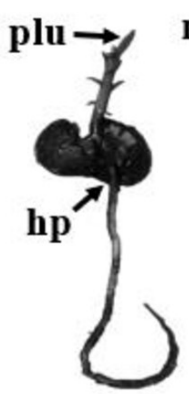

E

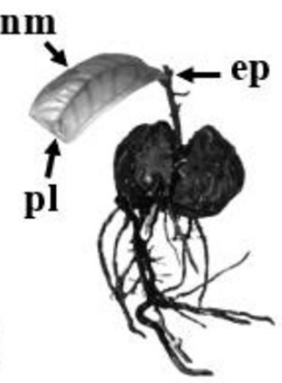

F

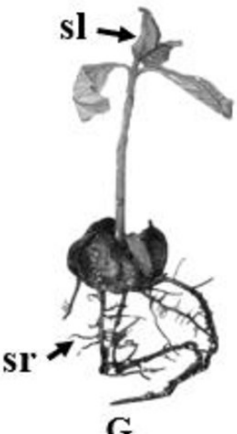

G

Figure 4. Sequence of $S$. malaccense germination: A) breaking of the integument (bi); B) opening of the cotyledons (ac); C) beginning of the emission of the primary roots (rp); D) primary roots (pr); E) plumule (plu), hypocotyl (hp); F) primary leaf (pl), nomophylls (nm), epicotyl (ep); G) second pair of leaves under expansion (sl), secondary roots (sr) S. malaccense and S. jambos present the hypogeal germination, emitting a primary root of white color (B), long, axial and whitish and after 23 weeks, it acquires a brown coloration $(\mathrm{F})$, which is marked by the beginning of the emission of the secondary roots $(\mathrm{G})$. The hypocotyl is cylindrical, initially presenting whitish color; the plumule $(\mathrm{C})$ presents purple coloration, very characteristic of the species, presenting the leaf primordia, then the first pair of leaves with light green coloration, forming an incomplete single leaflet, penninerved with linear format, presenting petiole, with elliptical limb.

The germination process and establishment of seedlings are extremely important to understand the population dynamics, the biological cycle and regeneration in natural conditions, being useful for the conservation of the species (DONADIO et al., 1998).

\section{Conclusion}

There is no influence of temperature within the tested in this study, on $S$. malaccense seed germination, whereas for $S$. jambos there is an impairment in the process when the seeds are subjected to the temperature of $35^{\circ} \mathrm{C}$.

Different temperatures which the seeds are subjected influences the percentage of polyembryony and the germination speed index for both species.
The seeds of S. malaccense and S. jambos present cotyledons of green coloration, hypogeal germination with primary root of brown coloration and whitish, short and filiform secondary roots.

\section{Acknowledgements}

Coordenação de Aperfeiçoamento de Pessoal de Nível Superior - Brasil (CAPES) for project financing. The Laboratory of Fruit Seeds of the Sciences of Agricultural Production, Department Plant Production. 


\section{References}

AGUIAR NETO, V.O.Influência do tamanho da sementena germinação do jambo-vermelho (Syzygium malaccense (L.) Merr \& Camp; L.M.Perry) sobre diferentes substratos. 2016. Dissertação (Mestrado) Universidade Federal do Maranhão, Chapadinha, 2016.

ALMEIDA, V.O. Estudos em mirtáceas em quatro municípios do recôncavo da Bahia. 2011. Dissertação (Mestrado) - Universidade Federal do Recôncavo da Bahia e Embrapa Mandioca e Fruticultura, Cruz das Almas, 2011.

AUGUSTA, I.M.; RESENDE, J.M.; BORGES, S.V.; MAIA, M.C.A.; COUTO, M.A.P.G. Caracterização física e química da casca e polpa de jambo vermelho (Syzygium malaccensis, (L.) Merryl \& Perry). Ciência e Tecnologia de Alimentos, Campinas, v.30, n.4, p.928-932, 2010.

BEWLEY, J.D.Germination. In: BEWLEY, J.D.; BRADFORD, K.J.; HILHORST, H.W.; NONOGAKI, H. Seeds: physiology of development, germination and dormancy. New York: Springer; 2013.p.133-181.

B ODRONE, M.P.; RODRÍGUEZ, M.V.; ARISNABARRETA, S.; BATLLA, D.Maternal environment and dormancy in sunflower: the effect of temperature during fruit development. European Journal of Agronomy, Amsterdam, v.82, p.93-103, 2017.

CARVALHO, N.M.; NAKAGAWA, J. Sementes: ciência, tecnologia e produção. 5.ed. Jaboticabal: Funep, 2012. 590 p.

COMBS J.K.; LAMBERT A.M.; REICHARD S.H.Predispersal seed predation is higher in a rare species than in its widespread sympatric congeners (Astragalus, Fabaceae). American Journal of Botany,Amsterdam, v.100, n.11, p.2149-2157, 2013.

COSTA, R.S.; OLIVEIRA, I.V.de M.; MORO, F.V.; MARTINS, A.B.G. Aspectos morfológicos e influência do tamanho da semente na germinação do jambo-vermelho. Revista Brasileira de Fruticultura, Jaboticabal, v.28, n.1, p.117-120, 2006.

DEWAN, S.; VANDER MIJNSBRUGGE, K.; DE FRENNE, P.; STEENACKERS, M.; MICHIELS, B.; VERHEYEN, K. Maternal temperature during seed maturation affects seed germination and timing of bud set in seedlings of European black poplar. Forest Ecology and Management, New York, v.410, p.126-135, 2018.

DONADIO, C.D.; NACHTGAL, J.C.; SACRAMENTO, C.K. Frutas exóticas Jaboticabal: FUNEP, 1998. p.115-118.
FERRAZ, M.V.; PIVETTA, K.F.L.; PRITCHARD, H.W.; MARKS, T.; FERRAZ, M.V.; GODOY, L.J.G. Germination response of ornamental pine seeds on a twoway thermogradient plate. American Journal of Plant Sciences, Lancaster, v.9, n.1, p.13, 2018.

GUIJARRO-REAL，C.; ADALID-MARTÍNEZ, A.M.; GREGORI-MONTANER, A.; PROHENS, J.; RODRÍGUEZ-BURRUEZO, A.; FITA, A. Factors affecting germination of Diplotaxis erucoides and their effect on selected quality properties of the germinated products. Scientia Horticulturae, Wageningen, v.261, p.109013, 2020.

GURGEL, J.T.A.; SOUBIHE SOBRINHO, J. Poliembrionia em mirtáceas frutíferas. Bragantia, Campinas, v.11, n.4-6, p.141-163, 1951.

HARTMANN, H.T.; KESTER, D.E.; DAVIES JR.F.T.; GENEVE, R.L. Plant propagation: principles and practices. 8.ed. Boston: Prentice Hall, 2011. p.340-540.

MAGUIRE, J.D. Speed of germination aid in selection and evaluation for seedling emergence and vigor. Crop Science, Madison, v.2, n.2, p.176-177, 1962.

MENDES-RODRIGUES, C.; OLIVEIRA, P.E.; RANAL, M.A. Seed germination and seedling growth of two Pseudobombax species (Malvaceae) with contrasting habitats from Brazilian Cerrado. Revista de Biologia Tropical, San Jose, v.59, n.4, p.1915-1925, 2011.

MENEZES, L.F.T.D.; PUGNAIRE, F.I., MATALLANA, G.; NETTESHEIM, F.C.; CARVALHO, D.C.D.; MATTOS, E.A.D. Disentangling plant establishment in sandy coastal systems: biotic and abiotic factors that determine Allagoptera arenaria (Arecaceae) germination. Acta Botanica Brasilica, São Paulo, v.32, n.1, p.12-19, 2018.

MWAMBURI, L.A.; LAING, M.D.; MILLER, R.M.Effect of surfactants and temperature on germination and vegetative growth of Beauveria bassiana. Brazilian Journal of Microbiology, São Paulo, v.46, n.1, p.67-74, 2015 .

OLIVEIRA, L.M.; BRUNO, R.D.L.A.; MENEGHELLO, G.E. Qualidade fisiológica de sementes de Syzygium cumini L.durante o armazenamento. Ciência Florestal, Viçosa, MG, v.25, n.4, p.921-931, 2015.

PATEL, A.G. Influence of type of cutting and IBA concentrations on rooting of wax apple (Syzygium samarangense L.) in mist chamber. 2016. Tese (Doutorado) - Navsari Agricultural University, Navsari, 2016. 
RIBEIRO, C.A.D., COSTA, M.D.P., SENNA, D.D.; CALIMAN, J.P. Fatores que afetam a germinação das sementes e a biomassa de plântulas de Tabebuia heptaphylla. Revista Floresta, Curitiba, v.42, n.1, p.161$168,2012$.

RYADIN, A.R.; RANAMUKAARACHCHI, S.L.; SONI, P.; SHRESTHA, R.P. Vegetative propagation of five local cultivars of malay apple (Syzygium malaccense spp.) in Ternate Island. International Journal on Advanced Science, Engineering and Information Technology,Yogyakarta, v.4, n.2, p.71-75, 2014.

SANTOS, J.P.; SANTANA, C.V.S.; SILVA, M.A.; ROCHA, R.C. Emergência e taxa de poliembrionia em sementes de mangueira (Mangifera indica), cultivar manguita e espada, com e sem tegumento. Revista Verde, Mossoró, v.4, n.4, p.49-53, 2009.

SANTOS, C.Q.D.J.; GIRARDI, E.A.; VIEIRA, E.L.; LEDO, C.A.D.S.; SOARES FILHO, W.D.S. Optimum sample size of fruits and seeds for polyembryony determination in citrus. Revista Brasileira de Fruticultura, Jaboticabal, v.37, n.1, p.172-178, 2015.
SEVIK, H.; CETIN, M. Effects of some hormone applications on germination and morphological characters of endangered plant species Lilium artvinense L.onion scales. Bulgarian Chemical Communications, Sofia, v.48, n.2, p.256-260, 2016.

TAIZ, L.; ZEIGER, E. Fisiologia vegetal. 6.ed. Porto Alegre: Artmed, 2017. p.240-480.

VYAS, S.V. Effect of time of air layering and iba on red jamun (syzygium samarangense l.) cv. Local 2404. 2017. These (Doctoral) - JAU Junagadh Agricultural University, Junagadh, 2017.

YUSNITA, Y.; JAMALUDIN, J.; AGUSTIANSYAH, A.; HAPSORO, D. A combination of IBA and NAA resulted in better rooting and shoot sprouting than single auxin on malay apple [Syzygium malaccense (L.) Merr.\& Perry] stem cuttings. AGRIVITA, Journal of Agricultural Science, East Java, v.40, n.1, p.80-90, 2017.

WAGNER JÚNIOR, A.; FRANZON, R.C.; COSTA SILVA, J.O.; SANTOS, C.E.M.; GONÇALVES, R.S.; BRUCKNER, C.H. Efeito da temperatura na germinação de sementes de três Espécies de jabuticabeira. Revista Ceres, Viçosa, MG, v.54, n.314, 2015. 